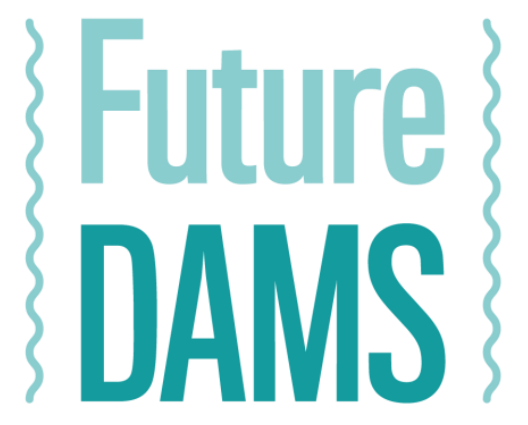

Design and Assessment of water-energy-food-environment

Mega-Systems

\title{
Theorising the political economy of dams: towards a research agenda
}

Tom Lavers ${ }^{1}$

Barnaby Dye ${ }^{2}$

${ }^{1}$ Global Development Institute, University of Manchester, UK Thomas.lavers@manchester.ac.uk

${ }^{2}$ Global Development Institute, University of Manchester, UK Barnaby.dye@manchester.ac.uk

\section{FutureDAMS}

Working Paper 001

March 2019

ISBN: 978-1-913093-01-3

Cite this paper as: Lavers, T and Dye, B (2019) Theorising the political economy of dams: towards a research agenda. FutureDAMS Working Paper 001. Manchester: The University of Manchester. 


\begin{abstract}
The politics of dams has been analysed from a range of disciplinary perspectives - including comparative politics, international relations, political economy and political ecology - and at varying levels - international, national and local. This paper provides a critical review of this literature, highlighting key research themes and gaps in current analysis as a means of developing a broad framework and research agenda for the FutureDAMS project. This framework emphasises the importance of integrating material and ideational drivers of dams across multiple levels of analysis. Much valuable work has been done on the international politics of dams and the micro-politics of displacement and resistance to dam construction. However, a comparatively neglected area of study - particularly where the recent dam boom in developing countries is concerned - is to link these transnational and micro-political processes to national-level decision making. To this end, the paper proposes a central concern with such national-level processes, including process tracing decision making, the distributional politics of energy, the development of bureaucratic and technical capacity to carry out dam projects and the companies contracted to build, assess and design dams.
\end{abstract}

\title{
Keywords
}

Political Economy, Political Ecology, Dams, Hydropower, Development Politics, Sustainability

\section{Acknowledgements}

FutureDAMS is funded by the Global Challenges Research Fund (GCRF). 


\section{Introduction}

This paper critically reviews the existing literature on the politics and political economy of dams, with a view to identifying key themes and current gaps in the literature, and to proposing a broad framework and research agenda to be pursued within the FutureDAMS project. The central concern of the FutureDAMS project is to understand how decisions about dams are made - from the identification of dams over other infrastructure as the preferred solution to perceived energy, food, environmental and water needs to the site selection, design, construction and operation of dams - with the aim of promoting better decision making throughout this process. While infrastructure development, including dam construction, is technologically challenging, it is also fundamentally political, with distributional and ideological dimensions that are a vital consideration. This paper proposes a research agenda that can both stand alone as a coherent programme of research on the politics of dams and complement and engage with the other social science and engineering research being conducted within FutureDAMS.

The study of dam politics is particularly pertinent given the infrastructure's current resurgence. Dam building went through a marked stagnation, starting from the 1980s but accelerating in the 1990s as a number of major funders like UNDP, the World Bank and European Export-Import (EXIM) banks pulled out or decreased dam finance (McCully 2001, Khagram 2004). This trend has, surprisingly, now been reversed for a number of reasons. Crucially, international finance has returned, particularly originating from emerging powers, foremost of which is China. Chinese government finance had increased from funding two dams in 2003 to at least 17 dams, and an accumulated spend of $\$ 13.3$ billion, by $2014 .{ }^{1}$ Additionally, in the context of climate change, Western donors and the World Bank have also returned, with dams presented as a sustainable energy source, approving $\$ 8.8$ billion for dam development and restoration between 2003 and 2014 (Bosshard, 2009; World Bank, 2009). Furthermore, the global commodities boom since the mid-2000s (Taylor, 2014) is a probable supplementary driver of the resurgence of dam construction: high food prices and, at points, severe challenges sourcing food in international markets are providing strong incentives for international and domestic investors, and national governments to pursue the expansion of agricultural production, with access to water and irrigation an important part of this process (Borras et al, 2011; Woodhouse, 2012). It is therefore important to assess potential continuities and change in this new era of dam construction.

Dams are fundamentally environmental interventions blocking the passage of a river and thereby change its hydrology, sediments, chemistry and other physical properties. Consequently, they directly and indirectly influence the ecosystem of a river, and the fauna and flora interrelated with the river's biophysical operation. However, such environments do not exist in separation from the human sphere. Rather, economies, cultures and societies are interrelated with rivers, using their material ecosystem services for food, water, transport and energy. Rivers also become cultural objects, for instance taking on spiritual or religious symbolism. This is captured by Swyngedouw (2015) and Hoag (2013) as the 'waterscape', a biophysically and socially produced hybrid environment. This connection between nature and society is also advanced by the hydro-social cycle, a term which conceptualises the processes by which water and society remake each other (Linton \& Budds, 2014). This gives hydro-social territories, 'spatial configurations of people,

\footnotetext{
${ }^{1}$ (Hwang et al. 2015, p. 12) Note that this differs from less reliable research citing China's engagement in 60 dams (International Rivers, 2014).
} 
institutions, water flows, hydraulic technology and the biophysical environment that revolve around the control of water' (Boelens et al, 2016, p 1).

Thus, dams' river intervention is inherently political, affecting different groups directly through displacement or indirectly through impacts on biophysical systems. This distributional impact is reinforced by questions of who is undertaking dam building and for what purpose. Dams have historically involved trade-offs between those whose livelihoods have been affected, especially through displacement, and those receiving electricity and water benefits. Thus, dams'

environmental intervention has the potential to benefit some to the detriment of others. Historically, this has favoured the economically and socially advantaged; water, and the associated benefits of controlling it, flow uphill. This reinforces the idea of dams and their environmental intervention as inherently political, serving certain interests while often entailing negative impacts for other ecologies and poorer people. Political ecology is therefore central to understanding dam building, grounding analysis in an appreciation of dams' ecological and political contexts, directing research to seek out the powerful interests driving or benefiting from dams, as well as the political effects of the infrastructure's ecological intervention (Adams, 1992; Hoag and Öhman, 2008; Everard, 2013; Tilt, 2015; Verhoeven, 2015a, 2015b; Olorunfemi et al, 2017; Tan-Mullins et al, 2018; Yankson et al, 2018).

As is clearly evident from the existing literature, dams are complex infrastructural developments that bring together a range of public and private, international and domestic actors. Moreover, dams can be assessed at multiple levels of analysis: from the international flows of finance, food and energy that constitute important drivers of the new dam boom to national governments that actively engage in trying to take advantage of and to re-shape these processes to address their own political and economic objectives to the local politics of changing land and water uses and the impact this has on livelihoods. As such, this paper proposes five analytically distinct but fundamentally interrelated levels of analysis relevant to the study of dams: the global political economy; the river basin and regional context; national political economy; sub-national regional dynamics; and the micro-politics of dams. The review emphasises that a focus on the national-level political economy - how dams are intertwined with political survival strategies and national economic development projects - has been comparatively neglected in much recent literature. While fundamentally linked to international and sub-national processes, this national political economy is a vitally important consideration with respect of the dam boom.

The paper proceeds in the following three sections by reviewing the literatures on the international, national and sub-national politics of dams, covering material that directly addresses the politics of dams and infrastructure, but also broader concerns with the political economy and state building. A final section, in place of a conclusion, synthesises this discussion into a broad framework that will guide FutureDAMS research on the politics of dams, and provides a preliminary research agenda.

\section{International dimensions of the political economy of dams}

The politics of dam design and construction cannot be considered solely within national borders. Important drivers of decision making - and no doubt in some contexts the key ones - are fundamentally international in character as a result of: the trans-boundary nature of many river basins; the international sources of finance for dam construction; the international companies and 
consultancies involved in their design and construction; and the international flows of fuel, food and water to which decision makers often seek to respond. Many river basins - including all those to be considered by the FutureDAMS project (the Tigris-Euphrates, Irrawaddy, Nile and Volta) - are distributed across national borders, with the result that water infrastructure built in one country has impacts upstream and/or downstream on other riparian countries. The relations of cooperation and/or conflict between riparian states are contingent upon a range of physical factors (eg dependence on and use of the river, alternative water sources) but, vitally, also on material power (economic or military), bargaining power (including the strategies pursued during negotiations to build alliances and outmanoeuvre opponents) and ideational/discursive power (deployed to frame issues and thereby shape national and international opinion) (Cascão \& Zeitoun, 2010; Kibaroglu, 2017). The concept of hydro-hegemony, drawing on broader thinking in international relations, has been developed to define situations in which one country establishes dominance in these strategic resources (Zeitoun and Warner, 2006) ${ }^{2}$. Trans-boundary relations in turn are shaped by historical legacies of conflict and cooperation, constraining the room for manoeuvre of national political elites. For instance, while often antagonistic, Nepal and Bhutan have cooperative agreements with India, where the regional hegemon lies downstream and builds hydropower infrastructure upstream, with the electricity then shared between builder and dam-host (Bisht, 2012; Lord, 2016). However the Mekong (Matthews, 2012; Tilt, 2015; Motta \& Matthews, 2018) and Nile (Mbaziira et al, 2005; Cascão, 2008; Mason et al, 2009; Cascão \& Zeitoun, 2010) constitute the most researched case study basins in this context.

Bilateral and multilateral relations with countries within a particular river basin constitute another vital element that has often shifted with geopolitical alignments. The Cold War, the subsequent period of relatively unchallenged US hegemony and the more recent era of the emerging powers challenging Western global dominance have each had important consequences for dam building in developing countries (Nicol \& Cascão, 2011; Verhoeven, 2016; Wu et al, 2016). One of the clearest mechanisms by which geo-strategic linkages influence dams is by limiting or enabling access to finance. During the Cold War, the US EXIM Bank became a major financer of dams, particularly in key allied states like Spain (Swyngedouw, 2007, 2015). Dam finance even became a proxy for contesting geopolitical alignment between cold war powers, with Ghana's President Nkrumah weighing up offers for the Akosombo Dam from the US and Russia, for instance. The World Bank, long one of the largest financers of dams, was of course not immune to such geostrategic manoeuvring on the part of the US. With the decline of Bank funding for dams in the 21st century and the rise of emerging powers like India, Brazil, the Arabian Gulf states and, most importantly, China, close relations with these new financers have become vital means of realising new dam projects.

These different international financiers are not only important as simple dam enablers, however, but also as key actors in the implementation process. In the 20th century a significant focus of the literature was on the policies and protests around the World Bank with regard to its impact assessment, mitigation and project approval protocols (Hildyard \& Willks, 1994; Goldman, 2005), culminating in the publication of the World Commission on Dams report in 2000. Such interests in the role of international financiers in dam building processes have continued into the 21st century, albeit with a focus primarily on China (Bosshard, 2009; McDonald et al, 2009; Tilt, 2015; Chen \&

\footnotetext{
${ }^{2}$ While noting that a key critique of this hydro-hegemony literature is its absence of political economy analysis.
} 
Landry, 2018; Siciliano \& Urban, 2018). These form part of wider debates on the politics of China's foreign relations and engagement in development projects, given its past unconditional acceptance of national construction quality and socio-environmental standards. With regard to countries in Africa, a popular narrative paints China's engagement as 'rogue aid' (Naim, 2009; Menon, 2012), exploiting helpless Africans and causing significant social and environmental damage. ${ }^{3}$ However, this problematically dismisses the agency of people and governments in Africa and the complexity of the actors and activities of the emerging powers (Bräutigam, 2011; Mawdsley, 2012; Power et al, 2012; Mohan \& Lampert, 2013). Others have sought to nuance this understanding, presenting the similarities, multiple actors and different potential outcomes from China's dam building and suggesting that there is nothing uniformly different about its international dam building compared to others (Hensengerth, 2013; Scheumann \& Hensengerth, 2014; Tan-Mullins et al, 2017; Siciliano \& Urban, 2018). Moreover, despite historically lower socio-environmental standards, China's EXIM Bank has adopted increasing requirements for its dam loans (Hensengerth, 2018). Understanding the motivations and processes of these enabling international financiers is therefore important.

While state investment in building capacity to plan and manage dams is highly likely to be an important factor shaping a coherent water-energy-food strategy, it is rare that developing countries will have the engineering and construction expertise to undertake dam construction alone. Rather, a relatively small number of engineering firms dominates the construction of large dams across the globe. These firms are increasingly divided into three groups. The first undertakes 'civil' construction, the physical concrete infrastructure. Such firms increasingly come from the Global South, led by major Chinese firms (Hwang et al, 2015), most notably Sinohydro, but also include Brazilian companies like Odebrecht and 'Western' firms such as the Italian Salini Impregilo. A second group undertakes the electro-mechanical engineering for hydropower projects. In this bracket, companies are typically from both Europe (eg Siemens, Voith, Lahmeyer International Germany) and the US (eg General Electric) or emerging powers (eg BHEL - India). The third group consists of large engineering conglomerates that design dams, supervise projects as Owner's Engineer and undertake river basin masterplans and environmental and social assessments. This latter group tends to originate in the West, particularly Canada (AECOM, SNCLavalin), Australia (SMEC) France (Coyne et Bellier, Artelia), Italy (Salini Impregilo) and Germany (Lahmeyer International).

Moreover, in the 21st century resurgence era private companies are increasingly taking on the role of dam developer. The liberalisation of electricity markets has resulted in the change from one organisation undertaking generation, transmission and distribution to these functions being undertaken by separate companies or organisations. Typically, developing countries have privatised power generation first, allowing private sector ownership and development of energy plants, which are then sold to a nationalised distributor using Power Purchase Agreement (PPA) contracts with these independent electricity-generating companies (Independent Power Producer IPP). Theoretically, this unleashes private sector capital for infrastructure generation; indeed, a number of countries, for instance Rwanda (Dye, 2019) and Uganda (Gore, 2017), have mobilised such investment to expand hydropower generation. However, these changes also have significant effects on the politics of dam building, changing norms of who is responsible for impact assessment, compensation, mitigation and benefit sharing, and introducing a profit motive that is

\footnotetext{
${ }^{3}$ In relation to dams, see the more empirically grounded analysis by Bosshard (2009) and McDonald et al (2009).
} 
potentially in tension with the 'public good' or at least the interests of affected rural peoples. While under-examined, this significantly complicates the type and number of corporate actors in the 21 st century dam-resurgence era (Ahlers et al, 2017).

The process of selecting and managing engineering firms is in itself political, whether it is insulated from political influence to ensure a technical decision based on specific qualifications, or whether the selection process involves corruption or favouritism. The process by which construction firms are selected to build dams would appear to be under-researched, no doubt because of the sensitivity of the topic. However, it is undoubtedly linked to geo-political alignments and, in many cases, to the access of national governments to global finance, with many deals involving joint finance-construction agreements. In other instances, however, the relationships between construction companies, hydro-bureaucracies and political elites dominate. For instance, they may be key to the meaningful inclusion of socio-environmental criteria in regional river basin planning. Such terms of reference may be dictated by international finance, but states frequently have influence over implementation and enforcement in the long term.

Towards the end of the 20th century anti-dam protests and questions over the efficacy of dam building - recently summarised by Ansar et al (2014) - provoked efforts to improve the planning and construction of dams. These include multilateral efforts, most notably the World Commission on Dams (WCD), but also industry initiatives, the most influential led by the International Hydropower Association (IHA). ${ }^{4}$ Key themes in these dam-building reforms include new commitments to: detailed, multi-dimensional and cumulative impact assessment; assessment of alternative projects to achieve irrigation, electricity and other desired services; participation in decision making, with the WCD calling for projects to be approved by affected communities; and a focus on mitigation in design and operation. The IHA captures a weaker version of these principles in the Hydropower Sustainability Assessment Framework, which ranks aspects of projects, including impact assessment. However, this framework does not incorporate legally binding promises for the people affected and has a technical focus on how dams are built rather than on the holistic considerations of alternatives or meaningful participatory engagement called for by the WCD.

Dams and the demand for their construction are also closely shaped by transnational commodity flows and the commodity boom of the 2000s that has recently subsided. Record prices for oil and other fossil fuels led governments to seek cheaper and potentially sustainable energy sources, with dams often framed among these alternatives. Furthermore, dams are also inextricably linked to food prices and production. Record food prices and shortages on global markets in the late 2000s were among the drivers of transnational and domestic agricultural investments - the so called 'land rush' - that sought to take advantage of these opportunities. In many cases agricultural investments are linked to the development and use of irrigation provided by dams (Bernstein, 2004; McMichael, 2009, 2010; Borras et al, 2010; Borras Jr \& Franco, 2012; Lavers, 2012). Whether the enthusiasm for large dam construction, which largely coincided with the commodity boom, persists now that commodity prices are much lower is open to question. While compatible to a degree, the desire to use dams for both irrigation and hydropower generation frequently requires trade-offs in both design and operation between these competing uses.

\footnotetext{
${ }^{4}$ Called the Hydropower Sustainability Assessment Protocol.
} 
Though international in their origins, the recent literature demonstrates that such reformist ideas regarding the planning and construction of dams are being picked up in dam practice (Dao, 2010; Skinner \& Haas, 2014; Dye, 2019). Increasingly, and in response to global protests, dam engineering companies have adopted the language of sustainability and corporate social responsibility. This may entail changes in dam construction policies, from the initiation of local compensatory development projects to engagement with communities during implementation and local procurement, employment and training. Perhaps unsurprisingly, a disconnect often exists between such policies on paper and on the ground, but there is evidence of rhetorical change and its translation to different practices (Dye, 2019).

\section{National level decision making}

An analysis of why dams are built, in what form, when and where must necessarily pay serious consideration to nation-states, which possess the ultimate (albeit sometimes severely circumscribed) power to approve dam construction within their territory. As discussed above, international relations, finance and commodity flows are vital enablers and constraints on dam construction within national territory. Yet it would be a mistake to assume - as seems to be implied in parts of the literature - that national governments in developing countries do not have agency to engage with and re-shape these processes to their own ends. The discussion below draws on diverse literatures, including that specifically focusing on dams, but incorporates also the broader literature on the politics of development and political sociology of the state. In doing so, the discussion synthesises three dimensions at the national level that are of particular importance to the analysis of dam construction: elite politics; technical and bureaucratic capacity; and finance.

\section{1 Elite politics and dams}

First, in terms of elite politics, recent work has highlighted the mutually constitutive nature of intraelite power relations, and formal and informal institutions (North et al, 2009, 2012; Khan, 2010; Hickey et al, 2015). From this perspective, formal political institutions or regime change are frequently less important than shifts in the power relations that underpin them. Variation in the distribution of power among elites and the institutional compromises that form the basis of 'political settlements' have important implications for the time horizon of the ruling coalition, the coherence of development strategies and state capacity to implement them. These insights have relevance to dam construction. The planning and construction of a dam is rarely possible within the timescale of one (or frequently several) electoral cycle and therefore requires some degree of political stability and long-term vision. It also requires the effective functioning of and coherent planning between multiple parts of the state, typically concerning environmental regulation, energy, finance, agriculture and land issues. Furthermore, dam construction requires time and commitment to develop local capacity in terms of long-term investments in engineering and other expertise, and mobilising sufficient finance. Additionally, dams necessarily have distributional impacts, creating winners and losers. As such, it is frequently necessary for the implementing organisations to override the resistance of these opposition groups and their political representatives.

Unsurprisingly, then, in terms of the importance of long time horizons, centralisation of power and ability to overcome resistance, dominant-party or authoritarian governments have been some of the most prolific dam builders. 
A more general insight from this literature is that politicians' interests and the balance of power between contending interest groups must be taken into account. Among the incentives for politicians, and engineering and finance actors, to support dams are the possibilities for corruption and self-enrichment. Large infrastructure projects are notorious for their corruption potential and dams are far from immune, with notable examples in Brazil (Poirier and Millikan, 2015; Poirier et al, 2015) and Argentina (Ribeiro, 1994). More generally, dams can form part of politicians' political survival strategies. Their capacity to provide services to particular communities - whether energy, irrigation or water - may be used to build support among key interest groups. Meanwhile, the negative impacts of dams - displacement and loss of water and associated environmental resources - are also key distributional costs that governments must weigh up, particularly in terms of the capacity of affected groups to mobilise and contest construction plans. While dams are frequently presented as solutions to national energy problems and as means to the extension of electricity access in order to secure popular support, achieving these objectives is far from simple. Frequently dam construction is not linked to a coherent strategy for extending electricity distribution into off-grid rural areas, which requires significant additional infrastructural investments. The distribution and use of hydropower is shaped by the relative political economic importance of industry, urban consumers, foreign exchange needs and rural populations. In such calculations the expansion of access to electricity may be more rhetoric than reality.

A focus on elite power relations and material interests, however, should not necessarily lead to a rationalist approach to understanding the politics of dams. The rational choice underpinnings of the political settlements framework, and the downplaying of ideational analysis within it, has been questioned (Lavers, 2018). Moreover, there is an abundant literature emphasising the importance of the ideological and discursive processes that shape dam construction (Swyngedouw, 2009; Menga, 2017). Indeed, rather than a rational planning exercise, there is a tendency for dam construction to become an article of faith for political elites, inherently intertwined with discourses of modernity, nation (re)building and the conquest of nature (Adams, 1992; Reisner, 1993; Hoag, 2005; Scott, 2006; Verhoeven, 2011; Everard, 2013; Menga, 2015; Swyngedouw, 2015; Dye, 2016). This often takes the form of high modernism, the ideology coined by Scott (1998) that is premised on a binary of backward, irrational and traditional peoples against those who are modern, civilised and rational, and with a unbending belief in the possibility of science and expertise to engineer better. Thus dams, given their monumentality, technological symbolism and ability to bring 'untamed' irrational natural resources to 'productive' industrial and agricultural purposes, have an affinity with the ideology (Tischler, 2013; van der Straeten, 2017).

The building of dams also performs development, which can again be important for enhancing the popular legitimacy of a leader, party or even the state in general. The monumental symbolism of a dam, and related praise for the infrastructure along high-modernist lines, can also elevate the infrastructure to the status of national icon, the image ubiquitous on bank notes and stamps. This nation-building role is made all the more potent in cases where dams are financed or built through popular mobilisation. Menga has analysed this in Tajikistan and Ethiopia, where citizens have been encouraged and, at times, coerced into contributing to grand dam projects (Menga, 2015, 2017; Menga and Swyngedouw, 2018). As such, research on elite politics must take into account both actors' perceived incentives resulting from the interaction of power relations and institutional forms, and the ideational foundations of political settlements and the ways in which policy ideas related to dams fit (or not) with particular problem framings and ideological orientations of political elites. 
There is also an international element to political strategies, with dam building able to cement alliances. For instance, Spain courted US patronage and protection under General Franco in the Cold War through its national hydro-building programme (Swyngedouw, 2015). In the dam-building resurgence, the discourse of 'sustainable development' has dominated. This provides a new justification for hydropower dam construction which can be framed by political elites in terms of 'green' and 'clean' energy production (Atkins, 2017, 2018). Additionally, interest in sustainability and climate change adaptation has produced discourse around the interdependent water-energyfood nexus (Hoff, 2011; Allan et al, 2015; Conway et al, 2015; Kurian, 2017). This new sustainable development discourse provides an opportunity for governments to build international legitimacy through hydropower dam construction, particularly when chosen over fossil fuels, demonstrating their credentials as responsible global actors engaged in global best practice. Moreover, this discourse has produced climate finance, with a significant amount of carbon credits funding dams. ${ }^{6}$

Meanwhile, many recent large dams are not just oriented to domestic energy markets but are designed to produce significantly more than current domestic requirements, with exports to regional energy markets and the generation of foreign exchange earnings in mind. This is well illustrated by the majority of East African countries, with Rwanda, Kenya, Tanzania and Ethiopia planning to sell electricity regionally. Particularly for Ethiopia, such plans constitute a key economic priority. They can increase export earnings, consequently easing balance of payments issues, and strengthen regional alliances. However, such trading necessitates strong institutionalised agreements and raises the question of whether regional markets will provide sufficient demand to meet new supplies. Again East Africa provides an interesting example, with plans for an Eastern Africa Power Pool long touted but still lacking institutional grounding. Given each country's strong presidentialism and frequent falling out, trading is happening, but only on a low-volume, bilateral basis.

\subsection{Technical and bureaucratic capacity}

The second component of the framework concerned with national-level politics focuses on bureaucratic capacity and the links between political elites and the hydro-bureaucracy. Political economy research has highlighted the importance of the bureaucracy as a semi-autonomous source of decision making, shaping the policy agenda and framing of problems (Grindle \& Thomas, 1991; Migdal, 2001; Grindle, 2012). This insight applies especially to dams, where agencies created to plan and construct them have often become powerful, agenda-setting actors in their own right, rather than merely implementing agencies to pursue the plans laid out by political elites. The importance of the bureaucracy highlights one limitation of the political settlements framework in its tendency to view the state as somewhat monolithic and homogeneous. Rather than a unitary actor, the state is better conceived as a network of semi-autonomous actors, each with their own interests and embedded in broader socio-political relations (Migdal, 1988, 2001; Hagmann \& Péclard, 2010).

\footnotetext{
${ }^{5}$ This is despite increasing evidence of the significance of methane production from reservoirs (particularly in tropical areas) (Fearnside, 2001, 2014) and given the potential risks entailed by increased rainfall variability from future climate changes (Conway et al, 2017).

${ }^{6}$ For example in China (Tilt, 2015) and Brazil's Belo Monte.
} 
Different literatures suggest quite different implications for the role of the bureaucracy in dam construction. On the one hand, a large literature emphasises the importance of Weberian characteristics - meritocracy, rational-legal administration, esprit de corps and sense of higher purpose, autonomy from political influence, empowerment to make decisions - in the functioning of effective bureaucracies with respect to economic development, service delivery and natural resource management (see Evans, 1995; Gerth \& Mills, 2003). Indeed, there are good reasons to expect that competent and effective dam construction would likewise be enabled by such a bureaucracy. On the other hand, however, there is a large critical literature on 'hydrocracies' (hydraulic bureaucracies) that problematises such agencies when they are too insulated and empowered (Molle et al, 2009). In many cases, hydrocracies are dominated by a rather narrow, techno-scientific worldview that focuses on controlling rivers and overcoming 'natural' obstacles, with the result that dams become the goal themselves, rather than a means to broader social and economic objectives. The premier example here is the Tennessee Valley Authority (TVA), which empowered experts to re-engineer the valley, removed from political pressures (Scott, 2006; Klingensmith, 2007). The TVA became globally regarded as a model for development that has been exported around world. ${ }^{7}$ The US Bureau of Reclamation provides a similar example in the west of the US of an agency whose central objective came to be to build dams and control nature, transforming a swathe of the country in the process (Worster, 1992; Reisner, 1993; Lowry, 2003). ${ }^{8}$ Again this is closely linked to ideology, and particularly high modernism, a key principle of which is the ability of science and expertise to derive the best paths to progress (Dye, 2019).

To some extent such divergent views of bureaucracy may be reconciled by moving away from the Weberian idea that effective bureaucracy is achieved through autonomy and insulation, which implies the necessity of extracting the bureaucracy from the realm of politics. Instead, all bureaucracies are necessarily products of the political environment from which they emerge, encompassing the purposes to which they are assigned, the freedom of manoeuvre that they achieve and the degree to which investments are made in developing competence and efficiency. Patronage may undermine bureaucratic effectiveness, but as Grindle (2012) demonstrates, political patronage does not necessarily destroy competence, but may be a means of ensuring that the bureaucracy meets both economic and political objectives. A prominent dams example here could be the US Bureau of Reclamation, which became an extremely effective dam builder (sometimes in spite of the infeasibility of the dams themselves), thanks to the way in which it was able to insert itself in and take advantage of the pork barrel system (of favouring local interests) in federal politics (Reisner, 1993).

The decision to undertake long-term investment in building bureaucracies' engineering and planning capacity through training and resources, to insulate (or not) hydro-bureaucrats from political influence, and the distribution of powers over the planning and construction of dams (centralised within one agency or dispersed over many) are all fundamentally political decisions that have enormous influence over national capacity to plan and build dams and the objectives

\footnotetext{
${ }^{7}$ Notable examples include Ghana's Volta River Authority, Tanzania's Rufiji Development Authority (Hoag, 2006) and East Africa's Kagera Basin Organisation (Dye, forthcoming). India's Damodar Valley Corporation provides the most direct example, however, with many of the TVA's advisors directly involved (Klingensmith, 2007).

${ }^{8}$ This model was also influential, with numerous developing-country leaders visiting its offices and projects, not least the notable dam-building presidents Nkrumah (Ghana), Nyerere (Tanzania), Nehru (India) and Nasser (Egypt) (Hoag, 2013).
} 
taken into account in the process. They are also distinctly under-researched, particularly in the most recent wave of dam building.

\subsection{Finance}

The final component of the national-level political economy concerns the ability to secure sufficient finance for dam construction. Finance may be sourced domestically or internationally (the latter considered above), but each method comes with particular constraints. The expansion of state capacity to mobilise taxes or contributions is a deeply political and transformative process for both state-society relations and, ultimately, the state itself (Migdal, 1988; Tilly, 1992). Generally, major expansions of revenue-generating capacity have resulted from either the need to mobilise resources in response to conflict or severe existential threats to ruling elites (Tilly, 1992; Moore, 2004; Bräutigam et al, 2008; Slater, 2010). In many developing countries, not only is the domestic resource base - and therefore the potential for domestic resource mobilisation - relatively small, but the political conditions which might favour the necessary expansion of state revenuemobilisation capacity are also absent. Once again, this literature highlights the importance of considering not just material interests but also ideational processes. The state's ability to mobilise resources through taxation is ultimately dependent on perceptions of state legitimacy and authority, as well as on the perceived significance of external threats.

In such contexts, international finance is the alternative and, where international finance is readily available, perhaps often a preferable one for elites compared with facing the challenges involved in raising domestic resources (Bräutigam et al, 2008). Moreover, international finance, for dams and other infrastructure, may be appealing to political elites as a means of securing resources that can then be used as part of their political survival strategies. Such extraversion enables political elites to take advantage of their dependent position within the global economy to consolidate their power domestically (Bayart, 2000). Verhoeven's (2015a) analysis of dam construction in Sudan provides such an example, where investment for dam construction is distributed through patronage networks to the political base. Consequently, given these factors and dam projects' frequently vast expense, international dam finance is the norm. The securing of this international money, from either development banks, governments or the private sector, is often therefore a key step in the lifecycle of any project consuming significant effort from national government. Particularly for larger dams, this is magnified by the number of planning, design and construction stages which may each need significant separate financing. The politics of how national elites procure such financing, and its influence on individual dams, is therefore an important process in dam building at the national level.

\subsection{Sub-national political dynamics and dams}

Alongside the international processes, national decision making regarding dam construction is equally inseparable from sub-national political dynamics encompassing bargaining with subnational elites; the distributional strategies implied in dam design and construction; the local impacts of dam construction - around the dam and reservoir, downstream and upstream - and political mobilisation to contest dam construction. As noted earlier, the pursuit of dam construction by political elites is often part of a strategy to build popular legitimacy through discourses of national rebirth and modernity. In such circumstances, what is very often proposed (implicitly or, occasionally, explicitly) is the sacrifice of those negatively affected by the dam - for example, 
through displacement, disruption of livelihoods or reduced water availability - for the greater good of national development.

The decision on whether and where to build a dam is further shaped by the historically embedded power relations between the national and sub-national level, and the institutional strategies employed by national political elites to govern sub-national jurisdictions (Migdal, 1988; Boone, 2003). These factors shape the extent of sub-national representation in the national-level decisionmaking process on dams, the choice of location and form of the dam, as well as agreements on the distribution of benefits and costs between national and sub-national levels. Depending on the power of sub-national elites, the latter may be able to secure a preferential balance of benefits and negative impacts for their region in agreements with national governments. The benefits may include access to water, irrigation, electricity and employment opportunities, while avoiding negative impacts such as displacement and loss of water access. Meanwhile, the construction and operation of a dam will in turn re-shape these political relations, providing new sources of revenue and economic opportunity, as well as disrupting existing livelihoods and economies. In the history of dam construction there has undoubtedly been a tendency to prioritise dams situated in politically marginal areas, enabling national elites to ignore sub-national elites in decision making, thereby building on, rather than challenging, historical processes of appropriation and marginalisation. ${ }^{9}$

Moreover, and particularly when planned and implemented in a top-down manner that disregards the interests of local populations, dams frequently engender various forms and degrees of popular resistance. Such resistance may include the overt: protest, campaigning and political mobilisation, sometimes linked to transnational NGOs and social movements promoting the protection of indigenous peoples or environmental sustainability, or may take the form of the covert 'weapons of the weak' (Scott, 1985). Perhaps the most famous example of such overt resistance is that to India's Narmada dam (Roy, 1999; D'Souza, 2002; Khagram, 2004), but dam projects have also been contested and occasionally defeated elsewhere in India (Mawdsley, 2005), Brazil (Fearnside, 1989, 2001; Khagram 2004), Myanmar (Kiik, 2016; Kirchherr et al, 2017), Laos (Goldman, 2005) and the US (Lowry, 2003). To a significant degree, the strategies of resistance pursued by affected populations are shaped by their capacity to mobilise considerable numbers of people, by the historically embedded nature of relations between the region in question and the centre of power in the country and by the ability of such movements to link to transnational actors able to support their opposition. Where affected populations are relatively few in number, or politically and economically marginalised, they may be limited to 'weapons of the weak', such as non-compliance with displacement and resettlement procedures.

Finally, the national decision-making process is shaped by dams' local impacts on livelihoods and economies. Key here are elite perceptions of the potential for any consequent political mobilisation to contest dams. Dams are inherently zero-sum investments - creating economic opportunities and revenue streams for some, but necessarily also imposing costs on others, most visibly those displaced, to make way for dams and reservoirs, but also potentially a wide range of others (Adams, 1992; Everard, 2013). While greater attention to the process and nature of resettlement programmes would be a positive step, the database created by Scudder, the authority in this field, finds that displaced people tend not to recover economically, even after 50 years (Scudder, 2005, 2012). Historically, decision makers at the national level frequently refuted the scale and variety of

\footnotetext{
${ }^{9}$ See Baviskar's (1995) case study of the Narmada.
} 
such impacts (McCully, 2001; Everard, 2013). This is partly because of their belief in social engineering to improve the livelihoods of the displaced, but also because of their faith in science and expertise to know and mitigate recognised environmental impacts (Dye, forthcoming; Dye, 2016; Havnevik, 1993; Öhman, 2007; Hoag and Öhman, 2008; Hoag, 2013, 2013). The underestimation of dams' impacts also stemmed from the top-down and exclusively expert workings of dam implementing organisations, which had only limited knowledge of the livelihoods and socio-ecological systems or services provided by the river. This is particularly reflected in impact assessments, which have historically overlooked downstream (Adams, 1992; Tsikata, 2006) and cumulative impacts (Everard, 2013; Kibler \& Tullos, 2013). When governments have recognised any impacts, these are frequently the most direct displacement from the dam site and reservoir area.

The brutal political calculation here is often one of who is politically expendable or, in some cases, which population groups are in need of transformation, drawing on deeply rooted ideas of the backwardness of particular livelihoods and the significance of modernity. Moreover, negative impacts of dam construction invariably have differential impacts by gender, class and ethnicity that will further shape the potential for affected groups to mobilise and resist (Tsikata, 2006; Öhman 2007). The nature of the impacts - real and perceived - alongside the capacity of affected populations to mobilise politically, shapes patterns of resistance.

\section{Conceptualising the politics of dams: a research agenda}

The proposed theoretical approach outlined in this paper emphasises the importance of both the material and ideational aspects of dams and the necessity of researching dams across multiple, interlinked levels of analysis. The project considers five analytically distinct yet interrelated levels of analysis. In addition to the national level, two of these are international in nature (the global and regional/river basin levels), while two are sub-national, comprising sub-national regions and the local area in which a dam and reservoir are situated.

The central focus for decision making about the planning and construction of dams is at the national level, where three factors - intra-elite political dynamics; technical and bureaucratic capacity; and finance - must come into alignment for dams to proceed. Nonetheless, while the research has a central analytical focus on the decision-making process at the national level, the intention is nonetheless to avoid the pitfalls of methodological nationalism. ${ }^{10}$ Each of these national factors is inherently intertwined in supra-national and sub-national political economic processes, necessitating a far broader analytical engagement in order to develop a nuanced understanding of the decision-making process surrounding dams.

The framework for the research builds on Migdal's (2001) 'State-in-Society' approach and on Hagmann and Péclard's (2010) 'Negotiating Statehood' framework. These theories view the state not as a monolithic entity but as a network of semi-autonomous organisations with their own distinct organisational interests and worldviews, each of which is embedded in society through both organisational ties to societal groups and the affiliation of individuals to particular networks, clubs,

\footnotetext{
${ }^{10} \mathrm{~A}$ concern that has been raised regarding both Khan's political settlements and Migdal's State-in-Society frameworks (Kohli \& Shue, 1994; Hickey, 2013), cited above.
} 
clans and ethnic groups. Crucially these frameworks enable analysis to differentiate between different parts of the state and to set an individual state organisation in a broader political context.

The research situates the energy sector and its key policies within the political survival strategies of national governments and includes both domestic and international dimensions. The research looks at the way ruling coalitions navigate global and regional political spheres, securing finance, expertise and political support for favoured dam projects, while mobilising these international resources to consolidate domestic power. As this suggests, however, international influences on policy choices are inseparable from domestic political economic calculations. Ultimately, decision making on electricity, as with development strategies more broadly, is distributional in nature, with state officials confronting multiple trade-offs across the levels of analysis within our framework. With respect to energy distribution, this entails balancing: between international export and domestic uses; between industrial and household consumption; between rural and urban areas; and between regions. Furthermore, such trade-offs also take place within the context of investment challenges - the need to construct transmission and distribution infrastructure; macroeconomic constraints - foreign exchange and budgetary issues, and they overlay intersecting social cleavages of class, ethnicity and region.

For illustrative purposes, Figure 1 presents a geographic conceptualisation of the key actors and processes that shape dam planning in a hypothetical country setting, showing how these actors and linkages might be distributed across the levels of analysis of the framework. Overall, the bulk of the existing literature tends to focus on one of two things: either the international dynamics shaping water governance within river basins and in terms of linkages to global actors (for example, on the Nile Basin, see Nicol \& Cascão, 2011; Salman, 2016; Tawfik, 2016a, 2016b; Yindego et al, 2016); or the local level impacts of dams and the response of local communities to them (Tsikata, 2006; Turton, 2011; Lavers, 2012; Kirchherr et al, 2017). Comparatively underresearched areas include the interlinkages between intra-elite relations, the hydro-bureaucracy and sources of domestic and international finance in the resurgence era, as well as the political economic relations shaping the choice of construction and engineering companies. The boxes and linkages in Figure 1 that represent the clearest gaps in the existing literature and, thus, where FutureDAMS could make significant contributions, are highlighted in orange. 
Figure 1. A hypothetical mapping of the key actors and processes shaping dam planning and construction

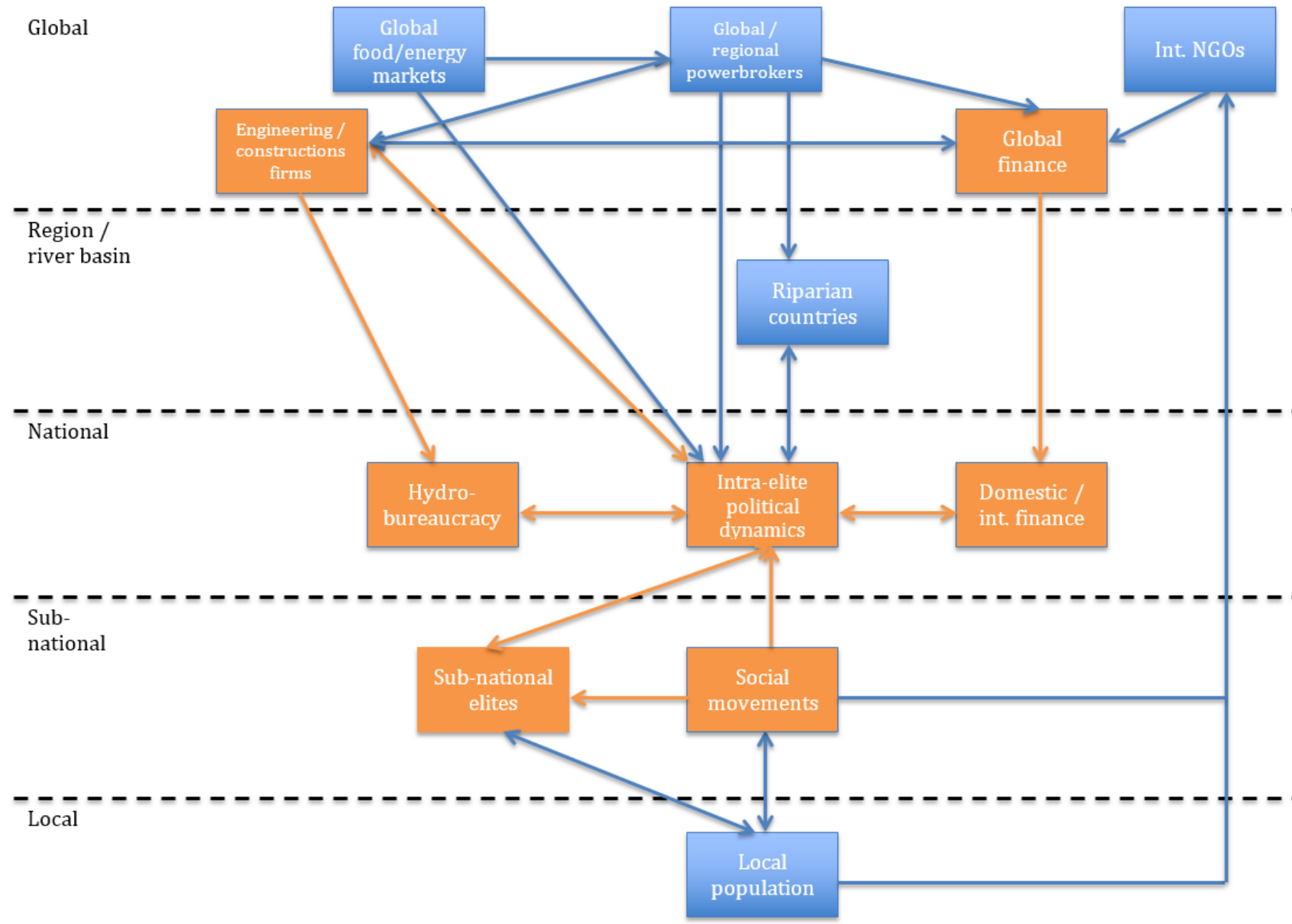

The proposal is therefore to focus empirical attention on these under-researched areas, while drawing on the existing literature regarding the broader global shifts and micro-level impacts of dams, which also feed into the political economy of decision making. To this end, the research will comprise four sub-projects focusing on key areas of interest:

\subsection{Historical analysis of the political economy of dam decision making}

The research will conduct an historical analysis of the process of decision making on dams, examining why dams are built in certain locations, according to certain designs and at certain points in time. Dams frequently have very long histories, with initial scoping studies identifying dam sites decades before construction begins. As such, a key focus is to trace the process to assess why technical capacity, finance and political commitment to dam construction all come together at one particular point in time and not at others.

\subsection{The politics of technical and bureaucratic capacity}

The research will focus on the state organisations charged with delivering dams. Are these technical dam building organisations created to deliver approved projects or are they themselves key actors driving decision making? To what degree have governments invested in building the technical capacities of these agencies? Do political dynamics empower these agencies to maximise technical capacities or subordinate these technical processes to political priorities? What opportunities do technical agencies provide to increase participation in decision making on dams? 


\subsection{The distributional politics of energy policy}

Dams are frequently justified as sustainable energy sources that can address national demand and extend electrification. How are decisions made about the relative prioritisation of electricity exports and domestic uses, including industry, urban and rural consumers? To what extent are dams linked to coherent infrastructure development plans to expand electrification in rural areas? Which groups are, or have been, prioritised in electrification and provision of electricity when faced with shortages? Do dams reflect real commitment to sustainable energy production or are they merely 'greenwashing' existing priorities?

\subsection{The political economy of companies}

This sub-theme will situate the companies involved in designing and constructing dams, assessing impacts and overseeing implementation standards with respect to political dynamics and linkages. How are these companies selected for projects and how is this shaped by connections to national political elites and financers? Are these companies themselves important actors in shaping decision making? What are the linkages between companies carrying out design and construction and those assessing impacts and standards? To what extent have these companies adopted new transnational ideas regarding improved decision making on dams? What freedom do they have to implement these?

\subsection{Sub-national responses to dam planning and construction}

Despite attempts to promote reformist ideas in dam planning and construction, the common tendency has long been for dams to be top-down initiatives that are primarily detrimental to adjacent communities, initiatives motivated primarily by the concerns of national political elites, within the constraints of the availability of international finance and expertise. Yet this raises questions concerning how sub-national actors from the affected areas respond to these initiatives. For example, to what degree are regional and ethnic elites from the affected areas able to negotiate and bargain with national governments to adapt plans and/or to ensure that the region benefits from the dam? Under what circumstances are social movements able to mobilise in opposition to dams? What strategies are most effective for contesting dams - disobedience and non-compliance, armed opposition or targeting international actors (powerbrokers, financiers or constructors) involved in the dam? 


\section{References}

Adams, W.M., 1992. Wasting the rain: rivers, people and planning in Africa. London: Earthscan.

Ahlers, R., Zwarteveen, M., and Bakker, K., 2017. Large Dam Development: From Trojan Horse to Pandora's Box. In: B. Flyvbjerg, ed. The Oxford handbook of megaproject management. Oxford: Oxford University Press.

Allan, T., Keulertz, M., and Woertz, E., 2015. The water-food-energy nexus: an introduction to nexus concepts and some conceptual and operational problems. International Journal of Water Resources Development, 31 (3), 301-311.

Ansar, A., Flyvbjerg, B., Budzier, A., and Lunn, D., 2014. Should we build more large dams? The actual costs of hydropower megaproject development. Energy Policy, 69, 43-56.

Atkins, E., 2017. Dammed and diversionary: The multi-dimensional framing of Brazil's Belo Monte dam: Dammed and diversionary. Singapore Journal of Tropical Geography, 38 (3), 276292.

Atkins, E., 2018. Dams, political framing and sustainability as an empty signifier: The case of Belo Monte. Area, 50 (2), 232-239.

Baviskar, A., 1995. In the belly of the river: tribal conflicts over development in the Narmada Valley. 1st Ed. Delhi ; New York: Oxford University Press.

Bayart, J.-F., 2000. Africa in the world: a history of extraversion. African Affairs, 99, 217-267.

Bernstein, H., 2004. 'Changing before our very eyes': Agrarian questions and the politics of land in capitalism today. Journal of Agrarian Change, 4 (1/2), 190-225.

Bisht, M., 2012. Bhutan-India Power Cooperation: Benefits Beyond Bilateralism. Strategic Analysis, 36 (5), 787-803.

Boelens, R., Hoogesteger, J., Swyngedouw, E., Vos, J., and Wester, P., 2016. Hydrosocial territories: a political ecology perspective. Water International, 41 (1), 1-14.

Boone, C., 2003. Political Topographies of the African State: Territorial Authority and Institutional Choice. Cambridge: Cambridge University Press.

Borras Jr, S.M. and Franco, J.C., 2012. Global Land Grabbing and Trajectories of Agrarian Change: A Preliminary Analysis. Journal of Agrarian Change, 12 (1), 34-59.

Borras, S.M., Hall, R., Scoones, I., White, B., and Wolford, W., 2011. Towards a better understanding of global land grabbing: an editorial introduction. Journal of Peasant Studies, 38 (2), 209-216.

Borras, S.M., McMichael, P., and Scoones, I., 2010. The politics of biofuels, land and agrarian change: editors' introduction. The Journal of Peasant Studies, 37 (4), 575.

Bosshard, P., 2009. China Dams the World. World Policy Journal, 26 (4), 43-51.

Bräutigam, D., 2011. The dragon's gift: the real story of China in Africa. 1st publ. in pbk. Oxford: Oxford Univ. Press.

Bräutigam, D., Fjeldstad, O.-H., and Moore, M., eds., 2008. Taxation and State-Building in Developing Countries. Cambridge: Cambridge University Press. 
Cascão, A.E., 2008. Ethiopia-Challenges to Egyptian hegemony in the Nile Basin. Water Policy, 10 (S2), 13.

Cascão, A.E. and Zeitoun, M., 2010a. Power, hegemony and critical hydropolitics. Transboundary water management. principles and practice, 27, 42.

Cascão, A.E. and Zeitoun, M., 2010b. Power, hegemony and critical hydropolitics. In: A. Earle and A. Jägerskog, eds. Transboundary water management: principles and practice. London; Washington, D.C: Earthscan.

Chen, Y. and Landry, D., 2018. Capturing the rains: Comparing Chinese and World Bank hydropower projects in Cameroon and pathways for South-South and North South technology transfer. Energy Policy, 115, 561-571.

Conway, D., Dalin, C., Landman, W.A., and Osborn, T.J., 2017. Hydropower plans in eastern and southern Africa increase risk of concurrent climate-related electricity supply disruption. Nature Energy, 2 (12), 946-953.

Conway, D., van Garderen, E.A., Deryng, D., Dorling, S., Krueger, T., Landman, W., Lankford, B., Lebek, K., Osborn, T., Ringler, C., Thurlow, J., Zhu, T., and Dalin, C., 2015. Climate and southern Africa's water-energy-food nexus. Nature Climate Change, 5 (9), 837-846.

Dao, N., 2010. Dam Development in Vietnam: The Evolution of Dam-Induced Resettlement Policy. Water Alternatives, 3 (2), 324-340.

D'Souza, D., 2002. The Narmada dammed: An inquiry into the politics of development. India: Penguin Books.

Dye, B., Forthcoming. The World Bank in the Resurgence of Dam-Building: Reformation of the Technician's Realm? European Journal of Development Studies.

Dye, B., 2016. The return of 'high modernism'? Exploring the changing development paradigm through a Rwandan case study of dam construction. Journal of Eastern African Studies, 10 (2), 303-324.

Dye, B., 2019. The Politics of Dam Resurgence: High Modernist Statebuilding and the Emerging Powers in Africa. University of Oxford, Oxford.

Evans, P.B., 1995. Embedded Autonomy: States and Industrial Transformation. Princeton, NJ: Princeton University Press.

Everard, M., 2013. The hydropolitics of dams: engineering or ecosystems? London; New York: Zed Books.

Fearnside, P.M., 1989. Brazil's Balbina Dam: Environment versus the legacy of the Pharaohs in Amazonia. Environmental Management, 13 (4), 401-423.

Fearnside, P.M., 2001. Environmental Impacts of Brazil's Tucuruí? Dam: Unlearned Lessons for Hydroelectric Development in Amazonia. Environmental Management, 27 (3), 377-396.

Fearnside, P.M., 2014. Impacts of Brazil's Madeira River Dams: Unlearned lessons for hydroelectric development in Amazonia. Environmental Science \& Policy, 38, 164-172.

Gerth, H.H. and Mills, C.W., 2003. From Max Weber: Essays in Sociology. London: Routledge.

Goldman, M., 2005. Imperial nature: the World Bank and struggles for social justice in the age of globalization. New Haven, Conn. ; London: Yale University Press. 
Gore, C., 2017. Electricity in Africa: the politics of transformation in Uganda. Oxford: James Currey.

Grindle, M.S., 2012. Jobs for the Boys. Cambridge, MA: Harvard University Press.

Grindle, M.S. and Thomas, J., 1991. Public Choices and Policy Change: The Political Economy of Reform in Developing Countries. London: John Hopkins University Press.

Hagmann, T. and Péclard, D., 2010. Negotiating Statehood: Dynamics of Power and Domination in Africa. Development and Change, 41 (4), 539-562.

Havnevik, K.J., 1993. Tanzania: the limits to development from above. [Uppsala] Sweden : [Dar es Salaam] Tanzania: Nordiska Afrikainstitutet; Mkuki na Nyota Publishers.

Hensengerth, O., 2013. Chinese hydropower companies and environmental norms in countries of the global South: the involvement of Sinohydro in Ghana's Bui Dam. Environment, Development and Sustainability, 15 (2), 285-300.

Hensengerth, O., 2018. China's investment in African hydropower: How to govern the waterenergy nexus? Evidence from the Bui Dam in Ghana. In: G. Siciliano and F. Urban, eds. Chinese hydropower development in Africa and Asia: challenges and opportunities for sustainable global dam-building. London: Routledge, Taylor \& Francis Group.

Hickey, S., 2013. Thinking About the Politics of Inclusive Development: Towards a Relational Approach. ESID Working Paper, 1.

Hickey, S., Sen, K., and Bukenya, B., 2015. The Politics of Inclusive Development: Interrogating the Evidence. Oxford University Press.

Hildyard, N. and Willks, A., 1994. Evicted!: The World Bank, British Aid and Forced Resettlement. Dorset: The Ecologist, Briefing by The Ecologist on the World Bank's 1994 Resettlement Review.

Hoag, H.J., 2005. The damming of Africa: The spread of river basin planning in post-war Africa. In: J.W.N. Tempelhoff, ed. African water histories: transdisciplinary discourses. Vanderbijlpark, South Africa: Vaal Triangle Faculty, North-West University.

Hoag, H.J., 2006. Transplanting the TVA? International Contributions to Post-war River Development in Tanzania. Comparative Technology Transfer and Society, 4 (3), 247-267.

Hoag, H.J., 2013. Developing the rivers of east and west Africa: an environmental history. London: Bloomsbury.

Hoag, H.J. and Öhman, M.-B., 2008. Turning Water into Power: Debates over the Development of Tanzania's Rufiji River Basin, 1945-1985. Technology and Culture, 49 (3), 624-651.

Hoff. H, 2011. Understanding the Nexus. Presented at the Conference The Water, Energy and Food Security Nexus: Solutions for the Green Economy: Stockholm Environmental Institute, Bonn.

Hwang, J., Bräutigam, D., and Wang, N., 2015. Chinee Engagement in Hydropower Infrastructure in sub-Saharan Africa. SAIS Working Paper: China-Africa Research Initiative, 2015/1.

International Rivers, 2014. China Overseas Dams List. Berkeley: California: International Rivers, Database Spreadsheet. 
Khagram, S., 2004. Dams and development: transnational struggles for water and power. Ithaca: Cornell University Press.

Khan, M., 2010. Political Settlements and the Governance of Growth-Enhancing Institutions. London: SOAS, Mimeo.

Kibaroglu, A., 2017. State-of-the-art review of transboundary water governance in the EuphratesTigris river basin. International Journal of Water Resources Development, 1-26.

Kibler, K.M. and Tullos, D.D., 2013. Cumulative biophysical impact of small and large hydropower development in Nu River, China: Biophysical Impact of Small and Large Hydropower. Water Resources Research, 49 (6), 3104-3118.

Kiik, L., 2016. Nationalism and anti-ethno-politics: 'why Chinese Development' failed at Myanmar's Myitsone Dam. Eurasian Geography and Economics, 57 (3), 374-402.

Kirchherr, J., Charles, K., and Walton, M.J., 2017. The interplay of activists and dam developers: the case of Myanmar's mega-dams. International Journal of Water Resources Development, 33 (1), 111-131.

Klingensmith, 2007. 'One valley and a thousand': dams, nationalism, and development. New Delhi: Oxford University Press.

Kohli, A. and Shue, V., 1994. State power and social forces: On political contention and accommodation in the Third World. In: J.S. Migdal, A. Kohli, and V. Shue, eds. State Power and Social Forces: Domination and Transformation in the Third World. Cambridge: Cambridge University Press, 108-40.

Kurian, M., 2017. The water-energy-food nexus. Environmental Science \& Policy, 68, 97-106.

Lavers, T., 2012. 'Land grab' as development strategy? The political economy of agricultural investment in Ethiopia. The Journal of Peasant Studies, 39 (1), 105-132.

Lavers, T., 2018. Taking ideas seriously within Political Settlements Analysis. ESID Working Paper, 95.

Linton, J. and Budds, J., 2014. The hydrosocial cycle: Defining and mobilizing a relationaldialectical approach to water. Geoforum, 57, 170-180.

Lord, A., 2016. Citizens of a hydropower nation: Territory and agency at the frontiers of hydropower development in Nepal: Nepalese hydropower development. Economic Anthropology, 3 (1), 145-160.

Lowry, W.R., 2003. Dam politics: restoring America's rivers. Washington, D.C: Georgetown University Press.

Mason, S.A., Hagmann, T., Bichsel, C., Ludi, E., and Arsano, Y., 2009. Linkages Between Subnational and International Water Conflicts: The Eastern Nile Basin. In: H.G. Brauch, Ú.O. Spring, J. Grin, C. Mesjasz, P. Kameri-Mbote, N.C. Behera, B. Chourou, and H. Krummenacher, eds. Facing Global Environmental Change. Berlin, Heidelberg: Springer Berlin Heidelberg, 325-334.

Matthews, N., 2012. Water Grabbing in the Mekong Basin: An Analysis of the Winners and Losers of Thailand's Hydropower Development in Lao PDR. Water Alternatives, 5 (2), 392-411.

Mawdsley, E., 2005. The Abuse of Religion and Ecology: the Visha Hindu Parishad and Tehri Dam. Worldviews: Global Religions, Culture, and Ecology, 9 (1), 1-24. 
Mawdsley, E., 2012. From recipients to donors: emerging powers and the changing development landscape. London; New York: Zed Books.

Mbaziira, R., Senfuma, N., and McDonnell, R., 2005. Institutional Development in the Nile Equatorial Lakes Sub-basin: Learning from the Experience of the Kagera Basin Organisation. Presented at the International Water Management Institute.

McCully, P., 2001. Silenced rivers: the ecology and politics of large dams. London; Atlantic Highlands, N.J., USA: Zed Books.

McDonald, K., Bosshard, P., and Brewer, N., 2009. Exporting dams: China's hydropower industry goes global. Journal of Environmental Management, 90, S294-S302.

McMichael, P., 2009. A food regime genealogy. The Journal of Peasant Studies, 36 (1), 139.

McMichael, P., 2010. Agrofuels in the food regime. The Journal of Peasant Studies, 37 (4), 609629.

Menga, F., 2015. Building a nation through a dam: the case of Rogun in Tajikistan. Nationalities Papers, 43 (3), 479-494.

Menga, F., 2017. Hydropolis: Reinterpreting the polis in water politics. Political Geography, 60, 100-109.

Menga, F. and Swyngedouw, E., 2018. States of Water. In: F. Menga and E. Swyngedouw, eds. Water, technology and the nation-state. London; New York: Routledge, Taylor \& Francis Group.

Menon, P., 2012. The Return of Empire in Africa? Harvard Political Review.

Migdal, J.S., 1988. Strong Societies and Weak States: State-Society Relations and State Capabilities in the Third World. Princeton, NJ: Princeton University Press.

Migdal, J.S., 2001. State in Society: Studying How States and Societies Transform and Constitute One Another. Cambridge: Cambridge University Press.

Mohan, G. and Lampert, B., 2013. Negotiating China: Reinserting African agency into China-Africa relations. African Affairs, 112 (446), 92-110.

Molle, F., Mollinga, P., and Wester, P., 2009. Hydraulic Bureaucracies and the Hydraulic Mission: Flows of Water, Flows of Power. Water Alternatives, 2 (3), 323-349.

Moore, M., 2004. Revenues, State Formation, and the Quality of Governance in Developing Countries. International Political Science Review / Revue internationale de science politique, 25 (3), 297-319.

Motta, S. and Matthews, N., 2018. Rewards and Risks of Chinese Hydropower in the Greater Mekong Subregion (GMS). In: G. Siciliano and F. Urban, eds. Chinese hydropower development in Africa and Asia: challenges and opportunities for sustainable global dambuilding. London: Routledge, Taylor \& Francis Group.

Naim, M., 2009. Rogue Aid: What's wrong with the foreign aid programs of China, Venezuela, and Saudi Arabia? They are enormously generous. And they are toxic. Foreign Policy.

Nicol, A. and Cascão, A.E., 2011a. Against the flow - new power dynamics and upstream mobilisation in the Nile Basin. Review of African Political Economy, 38 (128), 317-325. 
Nicol, A. and Cascão, A.E., 2011b. Against the flow - new power dynamics and upstream mobilisation in the Nile Basin. Review of African Political Economy, 38 (128), 317-325.

North, D.C., Wallis, J.J., Webb, S.B., and Weingast, B.R., 2012. In the Shadow of Violence: Politics, Economics, and the Problems of Development. Cambridge University Press.

North, D.C., Wallis, J.J., and Weingast, B.R., 2009. Violence and Social Orders: A Conceptual Framework for Interpreting Recorded Human History. Cambridge University Press.

Öhman, M.-B., 2007. Taming exotic beauties: Swedish hydropower constructions in Tanzania in the End of Development Assistance, 1960s-1990s. PhD Thesis. Department of History of Science and Technology, Royal Institute of Technology, Stockholm.

Olorunfemi, O.F., Tan-Mullins, M., Mohan, G., Siciliano, G., and Urban, F., 2017. Hope, Politics and Risk: The Case of Chinese Dam in Nigeria. Energy and Environment Research, 7 (2), 1.

Poirier, C. and Millikan, B., 2015. Mounting Evidence of Corruption in the Brazilian Dam Industry. Eye on the Amazon; Amazon Watch.

Poirier, C., Millikan, B., and Irigaray, M., 2015. Massive Corruption Scandal Implicates Brazil's Amazon Dam Builders. International Rivers, 4 Mar.

Power, M., Mohan, G., and Tan-Mullins, M., 2012. China's Resource Diplomacy in Africa: Powering Development? Houndmills, Basingstoke ; New York, NY: Palgrave Macmillan.

Reisner, M., 1993. Cadillac Desert. Revised and Updated ed. edition. New York, N.Y., U.S.A: Penguin Books.

Ribeiro, G.L., 1994. Transnational capitalism and hydropolitics in Argentina: the Yacyretá high dam. Gainesville: University Press of Florida.

Roy, A., 1999. The cost of living. Modern Library Pbk. ed. New York: Modern Library.

Salman, S.M.A., 2016. The Grand Ethiopian Renaissance Dam: the road to the declaration of principles and the Khartoum document. Water International, 41 (4), 512-527.

Scheumann, W. and Hensengerth, O., eds., 2014. Evolution of Dam Policies: Evidence from the big hydropower states. Berlin, Heidelberg: Springer Berlin Heidelberg.

Scott, J.C., 1985. Weapons of the Weak: Everday Forms of Peasant Resistance. New Haven, CT: Yale University Press.

Scott, J.C., 1998. Seeing Like a State: How Certain Schemes to Improve the Human Condition Have Failed. London: Yale University Press.

Scott, J.C., 2006. High Modernist Social Engineering: The Case of the Tennessee Valley Authority. In: L.I. Rudolph and J.K. Jacobsen, eds. Experiencing the state. New Delhi: Oxford University Press.

Scudder, T., 2005. The future of large dams: dealing with social, environmental, institutional and political costs. London; Sterling, VA: Earthscan.

Scudder, T., 2012. Resettlement Outcomes of Large Dams. In: C. Tortajada, D. Altinbilek, and A.K. Biswas, eds. Impacts of Large Dams: A Global Assessment. Berlin, Heidelberg: Springer Berlin Heidelberg, 37-67. 
Siciliano, G. and Urban, F., eds., 2018. Chinese hydropower development in Africa and Asia: challenges and opportunities for sustainable global dam-building. London: Routledge, Taylor \& Francis Group.

Skinner, J. and Haas, L., 2014. Watered down?: a review of social and environmental safeguards for large dam projects. London: International Institute for Environment and Development.

Slater, D., 2010. Ordering Power: Contentious Politics and Authoritarian Leviathans in Southeast Asia. Cambridge University Press.

van der Straeten, J., 2017. Transmitting Development Global Networks and Local Grids in the Electrification of East Africa, 1906-1970. Technischen Universität Darmstadt, Darmstadt.

Swyngedouw, E., 2007. Technonatural revolutions: the scalar politics of Franco's hydro-social dream for Spain, 1939?1975. Transactions of the Institute of British Geographers, 32 (1), 9-28.

Swyngedouw, E., 2009. The political economy and political ecology of the hydro-social cycle. Journal of Contemporary Water Research \& Education, 142 (1), 56-60.

Swyngedouw, E., 2015. Liquid power: water and contested modernities in Spain, 1898-2010. Cambridge, Massachusetts: The MIT Press.

Tan-Mullins, M., Urban, F., and Mang, G., 2017. Evaluating the Behaviour of Chinese Stakeholders Engaged in Large Hydropower Projects in Asia and Africa. The China Quarterly, 230, 464488.

Tan-Mullins, M., Urban, F., and Mang, G., 2018. The Political Ecology of Rising China: Case Study of Chinese Hydropower Dams in Africa and Asia. In: G. Siciliano and F. Urban, eds. Chinese hydropower development in Africa and Asia: challenges and opportunities for sustainable global dam-building. London: Routledge, Taylor \& Francis Group.

Tawfik, R., 2016a. The Grand Ethiopian Renaissance Dam: a benefit-sharing project in the Eastern Nile? Water International, 41 (4), 574-592.

Tawfik, R., 2016b. Changing Hydropolitical Relations in the Nile Basin: A Protracted Transition. The International Spectator, 51 (3), 67-81.

Taylor, I., 2014. Africa rising?: BRICS - diversifying dependency. Oxford: James Currey.

The World Bank, 2009. Directions in hydropower. Washington, DC: World Bank.

Tilly, C., 1992. Coercion, Capital, and European States, AD 990-1992. Cambridge, MA and Oxford: Blackwell Publishers.

Tilt, B., 2015. Dams and development in China: the moral economy of water and power. New York: Columbia University Press.

Tischler, J., 2013. Light and power for a multiracial nation: the Kariba Dam scheme in the Central African Federation. Houndmills, Basingstoke, Hampshire: Palgrave Macmillan.

Tsikata, D.A., 2006. Living in the Shadow of Ghana's Dams: Long Term Responses of Downstream and Lakeside Akosombo and Kpong Communities. Leiden ; Boston: Brill.

Turton, D., 2011. Wilderness, wasteland or home? Three ways of imagining the Lower Omo Valley. Journal of Eastern African Studies, 5 (1), 158-176. 
Verhoeven, H., 2011. Dams are Development: China the Al-Ingez Regime and the Political Economy of the Sudanese Nile. In: D. Large and L.A. Patey, eds. Sudan looks East: China, India \& the politics of Asian alternatives. New York: James Currey Ltd.

Verhoeven, H., 2015a. Water, civilization and power in Sudan: the political economy of militaryIslamist state-building. New York, NY: Cambridge University Press.

Verhoeven, H., 2015b. The nexus as a political commodity: agricultural development, water policy and elite rivalry in Egypt. International Journal of Water Resources Development, 31 (3), 360-374.

Verhoeven, H., 2016. Briefing: African dam building as extraversion: The case of Sudan's dam programme, Nubian resistance, and the Saudi-Iranian proxy war in Yemen. African Affairs, 115 (460), 562-573.

Woodhouse, P., 2012. New investment, old challenges. Land deals and the water constraint in African agriculture. The Journal of Peasant Studies, 39 (3-4), 777-794.

Worster, D., 1992. Rivers of empire: water, aridity, and the growth of the American West. Oxford: Oxford Univ. Press.

Wu, X., Jeuland, M., and Whittington, D., 2016. Does political uncertainty affect water resources development? The case of the Eastern Nile. Policy and Society, 35 (2), 151-163.

Yankson, P.W.K., Asiedu, A.B., Owusu, K., Urban, F., and Siciliano, G., 2018. The livelihood challenges of resettled communities of the Bui dam project in Ghana and the role of Chinese dam-builders. Development Policy Review, 36, O476-O494.

Yihdego, Z., Rieu-Clarke, A., and Cascão, A.E., 2016. How has the Grand Ethiopian Renaissance Dam changed the legal, political, economic and scientific dynamics in the Nile Basin? Water International, 41 (4), 503-511.

Zeitoun, M. and Warner, J., 2006. Hydro-hegemony-a framework for analysis of trans-boundary water conflicts. Water policy, 8 (5), 435-460. 